Article

\title{
Sheep Methane Emission on Semiarid Native Pasture-Potential Impacts of Either Zinc Sulfate or Propylene Glycol as Mitigation Strategies
}

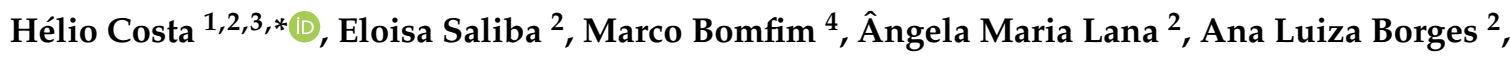 \\ Aline Landim ${ }^{1}$ D, Carlos Mota ${ }^{1}$, Rafael Tonucci ${ }^{4}$ and Antonio P. Faciola ${ }^{5}$ D \\ 1 Department of Animal Science, Vale do Acaraú State University, Sobral 62.040-370, Brazil; \\ alinelandim@yahoo.com.br (A.L.); carlosmikaell@gmail.com (C.M.) \\ 2 Department of Animal Science, Federal University of Minas, Belo Horizonte 30.123-970, Brazil; \\ saliba@ufmg.br (E.S.); lana@vet.ufmg.br (Â.M.L.); analuizavetufmg@gmail.com (A.L.B) \\ 3 Regional Scientific Development Scholarship of National Scientific and Technological Development \\ Council (Conselho Nacional de Desenvolvimento Cientifico e Tecnológico-CNPq)—Level \\ C (DCR-FUNCAP/CNPq), Brasilia 38706-400, Brazil \\ 4 Embrapa Goats and Sheep, Estrada Sobral-Groaíras, Km 04, Caixa Postal 145, Sobral 62010-970, Brazil; \\ marco.bomfim@embrapa.br (M.B.); rafael.tonucci@embrapa.br (R.T.) \\ 5 Department of Animal Sciences, University of Florida, Gainesville, FL 32611, USA; afaciola@ufl.edu \\ * Correspondence: helioa.costa@gmail.com; Tel.: +55-88-99999-3143
}

Received: 7 February 2020; Accepted: 25 February 2020; Published: 28 February 2020

Simple Summary: Feed availability for small ruminant production in the Brazilian semi-arid region is characterized by the seasonality of forage production over the year. Large variations of methane $\left(\mathrm{CH}_{4}\right)$ production have been reported among forage types and are mainly explained by the rate of fermentation of plant cell contents and the presence of various plant secondary compounds, notably in heterogeneous pasture. The aim of this study was to evaluate the effects of Zinc sulfate and propylene glycol (PG) on $\mathrm{CH}_{4}$ emission, nutrient intake, digestibility, and production in sheep grazing on a native Caatinga (Brazilian semi-arid savannah) pasture during the rainy season (from March to June 2014). Fifteen mixed Santa Inês sheep were distributed into three treatments (control, $\mathrm{Zn}$, and propylene glycol supplement) in this 112-day study. $\mathrm{CH}_{4}$ emission was measured using the $\mathrm{SF}_{6}$ tracer gas technique. Across the months of the trial, organic matter $(\mathrm{OM})$ and neutral detergent fiber (NDF) intakes were greater in March, while the greatest emission of $\mathrm{CH}_{4}$ (g/day) was observed in May. Total $\mathrm{CH}_{4}$ emission (kg) from March to June (112 days of evaluation) was greater in PG. In conclusion, our results indicate that $\mathrm{Zn}$ and PG have no beneficial effects in mitigating sheep $\mathrm{CH}_{4}$ emission when grazing Caatinga-native pasture in the rainy season.

Abstract: The aim of this study was to evaluate the effects of Zinc sulfate and propylene glycol (PG) on methane $\left(\mathrm{CH}_{4}\right)$ emission, nutrient intake, digestibility, and production in sheep grazing on a native Caatinga (Brazilian semi-arid savannah) pasture during the rainy season (from March to June 2014). Fifteen mixed Santa Inês sheep, all non-castrated males, with initial body weight of $19.8 \pm 1.64 \mathrm{~kg}$, and $4 \pm 0.35$ months of age, were distributed in a complete randomized design into three treatments: control (CT) - concentrate supplemented at $0.7 \%$ of body weight; $\mathrm{CT}+300 \mathrm{mg}$ of $\mathrm{Zn} /$ day; and CT + $2.5 \mathrm{~mL}$ of propylene glycol $/ \mathrm{kg} \mathrm{LW}{ }^{0.75} /$ day. Measurements were done in four periods during the rainy season, with 28 days of interval between each measurement. $\mathrm{CH}_{4}$ emission was measured using the $\mathrm{SF}_{6}$ tracer gas technique. $\mathrm{CH}_{4}$ emission per day was greater in PG than in $\mathrm{CT}$ and $\mathrm{Zn}(p<0.05)$. However, no additive effect was observed on the intakes of organic matter $(\mathrm{OM})$ and neutral detergent fiber (NDF), or on $\mathrm{CH}_{4}$ emission expressed as a function of OM and NDF intakes ( $\left.p>0.05\right)$. Across the months of the trial, OM and NDF intakes were greater in March, while the greatest emission of $\mathrm{CH}_{4}\left(\mathrm{~g} /\right.$ day and $\mathrm{g}$ by $\mathrm{g} / \mathrm{OM}$ intake) was observed in May $(p<0.05)$. Total $\mathrm{CH}_{4}$ emission $(\mathrm{kg})$ from 
March to June (112 days of evaluation) was greater in PG compared with CT and $\mathrm{Zn}(p<0.05)$. Zinc and PG had no effect on total $\mathrm{CH}_{4}$ emission when it was expressed per unit of body weight gain or carcass production $(p>0.05)$. The results of this study indicate that Zinc sulfate and propylene glycol have no beneficial effects in mitigating sheep $\mathrm{CH}_{4}$ emission. The $\mathrm{CH}_{4}$ emissions originated from sheep grazing native Caatinga pasture change throughout the rainy season due to fluctuations in availability and quality of pasture biomass. Moreover, the inclusion of zinc sulfate or propylene glycol did not improve animal feed intake, nutrient digestibility, and animal performance.

Keywords: Caatinga; $\mathrm{CH}_{4}$; rainy season; $\mathrm{SF}_{6}$

\section{Introduction}

Methane $\left(\mathrm{CH}_{4}\right)$ production through enteric fermentation is a global matter of concern due to its contribution to greenhouse gases (GHG) accumulation in the atmosphere. Enteric fermentation emissions in Brazil increased nearly threefold in the last 40 years [1]. $\mathrm{CH}_{4}$ emissions in the livestock sector come from this natural digestive process, where countries from Latin-America contribute with $20.9 \mathrm{Tg} \mathrm{CH}_{4} / \mathrm{yr}$, representing about $15 \%$ to the global enteric fermentation emissions of $104 \mathrm{Tg}$ $\mathrm{CH}_{4} / \mathrm{yr}[1,2]$. This process also represents a loss of dietary energy by the animal, with $5-9 \%$ of the dietary gross energy being lost this way [3,4]. Therefore, reducing $\mathrm{CH}_{4}$ emissions can mitigate the impact of the livestock sector on climate change, improve energy utilization, and animal performance.

Reductions in $\mathrm{CH}_{4}$ emissions by livestock are associated with improvements in diet quality, e.g., high nutritive pastures and feed supplementation [5]. Effective mitigation strategies should enable a reduced cost of meat production, which is associated to greater energy utilization, in addition to reductions in $\mathrm{CH}_{4}$ emissions per unit of product produced [6,7].

Feed availability for small ruminant production in the Brazilian semi-arid region is characterized by the seasonality of forage production over the year. Because the rainfall is concentrated in a short period of the year, January to May [8,9], the availability and quality of forage are compromised during the dry season. Thus, large variations in $\mathrm{CH}_{4}$ emission have been reported among forage types and are mainly explained by the rate of nutrient fermentation and the presence of various plant secondary compounds, notably in heterogeneous pastures in semiarid conditions [10].

Several possibilities for reducing emissions of $\mathrm{CH}_{4}$, mainly, with grazing animals have been suggested. Out of these, the most used strategy is the inclusion of feed additives with the objective of manipulating the ruminal environment in order to improve nutrient intake, fermentation efficiency, and increase animal production [11]. The supply of nutrients such as proteins and minerals (e.g., zinc) and greater energy intake (e.g., using propylene glycol) can improve nutrient intake and feed utilization, thereby minimizing energy losses [12].

$\mathrm{Zn}$ is generally added to diets to ensure that nutritional requirements are met; however, dietary Zn supply for ruminants often exceeds the actual requirements [13]. It has been observed that the inclusion of $100 \mathrm{ppm}$ of $\mathrm{Zn}$ affects animal response to protein supplementation and utilization of low-quality forages by affecting ruminal fermentation traits [14]. The supplementation of $20 \mathrm{mg} \mathrm{Zn} / \mathrm{kg}$ $\mathrm{DM}$ as Zn-methionine in a basal diet containing $34 \mathrm{mg} \mathrm{Zn/kg} \mathrm{DM} \mathrm{for} \mathrm{lambs} \mathrm{significantly} \mathrm{improved} \mathrm{fiber}$ digestibility and growth rate [15]. In addition, studies have demonstrated that supplementation of organic and inorganic combinations of Zn may enhance performance and improve health of sheep [13]. These reports indicate that ruminants can be fed high-Zn diets without adverse effects [13].

Propylene glycol (PG) can increase ruminal propionate concentration and consequently decrease $\mathrm{CH}_{4}$ production in the rumen $[16,17]$, which is energetically favorable to the animal. In vitro studies, with sheep ruminal content, indicate that the main products of PG fermentation were propanol and propionate [18]. A review performed by Nielsen and Ingvartsen [19] reported that propionate is the predominant end product of PG fermentation. PG addition decreased the acetate:propionate ratio in 
the rumen because part of PG is metabolized to propionate in the rumen. The fermentation of PG in the rumen is further characterized by producing $\mathrm{CO}_{2}$ and significant inhibition of $\mathrm{CH}_{4}$ production, resulting in less energy loss [18]. Moreover, in a study with lambs, the addition of $4 \%$ dietary PG had no difference in feed intake and performance, possibly due to relatively low dietary protein and diet digestibility [20]. The inconsistency in research findings when Zn and PG were fed to sheep justifies the need for studies evaluating their effects on feed intake, nutrient digestibility, and $\mathrm{CH}_{4}$ emissions.

Therefore, our hypothesis was that zinc and propylene glycol would reduce methanogenesis in sheep grazing native pastures in the semiarid region of Caatinga. The aim of this study was to evaluate the effects of zinc sulfate and propylene glycol on $\mathrm{CH}_{4}$ emissions, nutrient intake, and production from sheep grazing in a native Caatinga (Brazilian semi-arid savannah) pasture during the rainy season.

\section{Materials and Methods}

\subsection{Animal Use}

Animal handling and procedures involving all experimental animals were undertaken according to protocols approved by the Ethics Committee on Animal use of the Federal University of Minas Gerais (CEUA/UFMG, no. 321/2013).

\subsection{Characterization of the Experimental Area}

The study was conducted at Embrapa Goats and Sheep, located in the state of Ceará, Northeast Brazil ( $3^{\circ} 45^{\prime} 51.59^{\prime \prime} \mathrm{S}$ and $40^{\circ} 21^{\prime} 04.24^{\prime \prime} \mathrm{W}, 92 \mathrm{~m}$ asl). Eight hectares of a native Caatinga pasture area were thinned according to Araújo Filho [21]. The area's predominant soils were litolic dystrophic, planosol and non-calcium brown. The experiments were executed during the rainy season (March to June 2014), with a precipitation of $514 \mathrm{~mm}$ (Figure 1) and average temperature and air humidity of $26.5^{\circ} \mathrm{C}$ and $78.0 \%$, respectively [22].

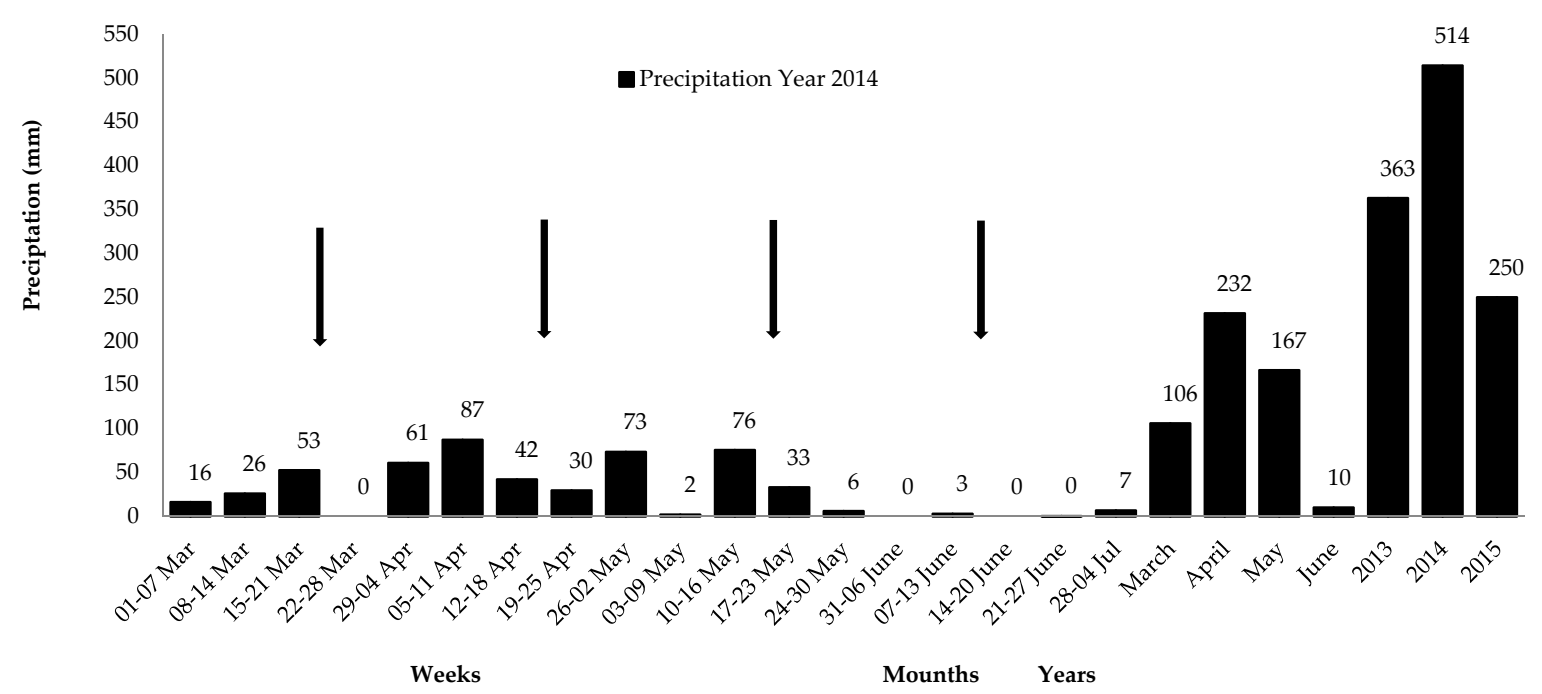

Figure 1. Weekly and monthly precipitation from March to June 2014 and yearly precipitation during the assessment in 2013, 2014, and 2015. Arrows indicate collection weeks in each month. Source: [22].

\subsection{Animals and Experimental Treatments}

Fifteen mixed Santa Inês sheep, all non-castrated males, with initial body weight of $19.8 \pm 1.64 \mathrm{~kg}$, and $4 \pm 0.35$ months of age, were distributed in a complete randomized design into three treatments: control (CT)—concentrate supplemented at $0.7 \%$ of body weight; $\mathrm{CT}+300 \mathrm{mg}$ of $\mathrm{Zn} /$ day; and $\mathrm{CT}+2.5 \mathrm{~mL}$ of propylene glycol $/ \mathrm{kg} \mathrm{LW} \mathrm{LW}^{0.75} /$ day.

Animals were kept in continuous stocking and weighed weekly to monitor daily body weight gain and supplementation feeding. All animals had free access to mineral salt, with compositions 
of: $\mathrm{Ca}=82.0 \mathrm{~g} / \mathrm{kg}, \mathrm{Co}=30.0 \mathrm{mg} / \mathrm{kg}, \mathrm{Cu}=350 \mathrm{mg} / \mathrm{kg}, \mathrm{Cr}=11.7 \mathrm{mg} / \mathrm{kg}, \mathrm{S}=11.7 \mathrm{~g} / \mathrm{kg}, \mathrm{P}=60.0 \mathrm{~g} / \mathrm{kg}$, $\mathrm{I}=50.0 \mathrm{mg} / \mathrm{kg}, \mathrm{Mn}=1200 \mathrm{mg} / \mathrm{kg}, \mathrm{Mo}=180 \mathrm{mg} / \mathrm{kg}, \mathrm{Se}=15 \mathrm{mg} / \mathrm{kg}, \mathrm{Na}=132 \mathrm{~g} / \mathrm{kg}$, and Zn $=2600 \mathrm{mg} / \mathrm{kg}$.

The daily $\mathrm{Zn}$ dosage required to increase concentration in ruminal fluid at $300 \mathrm{mg} \mathrm{Zn/day} \mathrm{was}$ calculated. The amount of $\mathrm{Zn}$ was established considering the concentration in the mineral salt and the addition of $\mathrm{ZnSO}_{4} \cdot 7 \mathrm{H}_{2} \mathrm{O}$. The amounts of salt and zinc sulfate supplied to the animals were weighed and mixed prior to being provided and adjusted to not contain leftovers. For $\mathrm{Zn}$ supplementation, the procedures described by Arelovich et al. [23] and the maximum tolerable level of toxicity for sheep according to NRC (2007) [24] were used. PG was supplied at $2.5 \mathrm{~mL} \times \mathrm{kgLW}^{0.75}$ animal/day [17], and mixed directly into concentrate. PG supply was adjusted weekly, according to the group's average body weight in $\mathrm{kgLW}^{0.75}(n=5)$.

A stocking rate of $0.4 \mathrm{ha} /$ head was used, considering an animal of $30 \mathrm{~kg}$ of LW [21]. The animals were taken to the pasture at 07:00 and brought back at 16:00, when they were supplemented according to treatments. The concentrate was composed of corn ( $540 \mathrm{~g} / \mathrm{kg} \mathrm{DM})$, soybean meal $(451 \mathrm{~g} / \mathrm{kg} \mathrm{DM})$ and limestone $(9.0 \mathrm{~g} / \mathrm{kg} \mathrm{DM})$, formulated as recommended by the NRC (2007) [24], for finishing lamb with a predicted average daily gain of $150 \mathrm{~g}$.

\subsection{Forage Availability and Botanical Composition}

Before the start of the experimental period, the occurrence of the main forage groups and species were determined using the method proposed by Araújo Filho [21], with a frame measuring $0.25 \mathrm{~m}^{2}$ and systematically arranged along lines, every $4 \mathrm{~m}$, totaling 50 sampling points. The percentage of the main forage species of the herbaceous stratum in the area was analyzed. Forage availability in weight was estimated by collecting the forage from the herbaceous stratum contained within the frame every $12 \mathrm{~m}$. The material was weighed and oven dried at $55^{\circ} \mathrm{C}$ for $72 \mathrm{~h}$ to calculate DM/ha availability (Table 1).

Table 1. Herbaceous stratum availability, expressed as DM (Dry Matter), and floristic composition of Caatinga-native pasture in the rainy season.

\begin{tabular}{ccccc}
\hline & \multicolumn{2}{c}{ DM Availability, $\mathbf{k g} / \mathbf{h a}$} & & \multicolumn{2}{c}{ Floristic Composition, $\mathbf{g} / \mathbf{k g}$} \\
\hline Legumes & Grasses & Total & Legumes & Grasses \\
\hline 1364 & 533 & 1897 & 719 & 281 \\
\hline
\end{tabular}

\subsection{Determination of Nutrient Intake and Pasture Sampling}

Four intake and digestibility measurements were carried out in the rainy season during the months of March to June, with an interval of 28 days between periods. To determine total intake, external indicator LIPE ${ }^{\circledR}$ (patent No BR0304736-9) was administered orally in the morning, at a dose of $0.25 \mathrm{~g}$ per animal/day, for a period of 7 days, with 2 days for adaptation and stabilization of the indicator in the gastrointestinal tract, and 5 days for fecal collection [25]. Fecal samples were collected directly from the animals' rectum, stored in plastic bags and frozen in a freezer at $-20^{\circ} \mathrm{C}$. Samples composed by animal, by period, were dried at $55.0^{\circ} \mathrm{C}$ for $72 \mathrm{~h}$ and milled so as to determine LIPE ${ }^{\circledR}$ concentration in the feces and estimate fecal production (FP), as per the equation below:

Fecal production, $\mathrm{g} /$ day $=\left(\mathrm{LIPE}^{\circledR}\right.$ supplied, $\mathrm{g} / \mathrm{LIPE}^{\circledR}$ recovered in feces, $\left.\mathrm{g}\right) \times$ fecal DM, $\mathrm{g} / \mathrm{kg}$

To assess digestibility and forage chemical composition (Table 2), two ruminally-cannulated adult sheep were used, with mean body weight of $34.5 \pm 2.1 \mathrm{~kg}$. Ruminal extrusa samples were collected as described by Olson [26], for 5 consecutive days in each experimental period, starting 1 day before feces collection using the animals used for intake determination. The collection procedure consisted of emptying all ruminal content, which was stored in clean plastic containers. Then, animals were 
allowed to graze for 1 hour. After this time, all ruminal extrusa were collected. After that, the ruminal content initially removed was returned to the rumen.

Table 2. Composition of ruminal extrusa samples ${ }^{\dagger}$ collected from sheep on Caatinga-native pasture during the rainy season.

\begin{tabular}{|c|c|c|c|c|c|}
\hline \multirow{2}{*}{ Variables } & \multicolumn{4}{|c|}{ Periods } & \multirow{2}{*}{ Concentrate ${ }^{\beta}$} \\
\hline & March & April & May & June & \\
\hline $\begin{array}{c}\text { Dry Matter }{ }^{¥}, \mathrm{~g} / \mathrm{kg} \\
\mathrm{g} / \mathrm{kg} \mathrm{DM}\end{array}$ & 118 & 128 & 142 & 158 & 877 \\
\hline OM & 819 & 810 & 798 & 819 & 913 \\
\hline Crude Protein & 192 & 187 & 176 & 131 & 254 \\
\hline $\begin{array}{l}\text { Neutral Detergent Insoluble Nitrogen } \\
\text { (NDIN) }\end{array}$ & 2.99 & 2.87 & 3.03 & 3.01 & 3.04 \\
\hline NDIN, $\%$ of total nitrogen & 98.3 & 96.3 & 108 & 145 & 74.6 \\
\hline Ether Extract & 76.0 & 76.5 & 86.8 & 111 & 64.0 \\
\hline Neutral Detergent Fiber & 524 & 590 & 610 & 564 & 159 \\
\hline $\begin{array}{c}\text { Ash-free values of Neutral Detergent } \\
\text { Fiber (aNDFom-NDF) } \ddagger\end{array}$ & 437 & 496 & 504 & 478 & 113 \\
\hline Acid Detergent Fiber & 430 & 476 & 487 & 473 & 103 \\
\hline Hemicellulose & 94.1 & 114 & 123 & 91.5 & 56.1 \\
\hline Cellulose & 208 & 250 & 261 & 243 & 45.6 \\
\hline Acid Detergent Lignin & 35.4 & 45.4 & 52.5 & 37.8 & 11.3 \\
\hline Klason Lignin & 40.7 & 50.4 & 65.4 & 52.8 & 17.8 \\
\hline Total tannins & 0.64 & 8.14 & 8.33 & 14.8 & - \\
\hline In Vitro Dry Matter Digestibility ${ }^{\dagger}$ & 537 & 408 & 424 & 441 & 954 \\
\hline In Vitro Organic Matter Digestibility & 468 & 333 & 353 & 359 & 939 \\
\hline
\end{tabular}

${ }^{\dagger}$ Ruminal extrusa samples collected prior to rumen emptying after a 1-hour grazing in thinning Caatinga area,

${ }^{\dagger}$ In Vitro Dry Matter Digestibility to according to [27]; ${ }^{\beta}$ Corn, soybean meal, and limestone; ${ }^{¥}$ Dry matter on a as

fed basis; ${ }^{\ddagger}$ aNDFom-NDF assayed with a heat stable amylase and expressed exclusive of residual ash NDF.

Total OM intake was calculated using fecal DM production estimated by a LIPE ${ }^{\circledR}$ indicator by [28]:

$$
\text { Intake (g OM/day) = Production of fecal DM (g/day)/1-IVOMD/100 }
$$

\subsection{Determination of Enteric $\mathrm{CH}_{4}$ Emission}

Gases were collected in four occasions, with a 28-day interval, right after the intake measurements. $\mathrm{CH}_{4}$ emitted by the animals was determined by the $\mathrm{SF}_{6}$ tracer gas technique [29] with adjustments for measurements in sheep. The $\mathrm{SF}_{6}$ permeation tubes that were used had average permeation rates of $1099 \mathrm{mg} /$ day. The tubes were deployed in the animals' reticulum (per dosing), 28 days before the first collection. The collection was performed for two consecutive $48 \mathrm{~h}$ periods, per animal, monthly. The $\mathrm{SF}_{6}$ capsules were calibrated to release 1-2 mg of $\mathrm{SF}_{6}$ every $24 \mathrm{~h}$, considering that the $\mathrm{SF}_{6}$ and $\mathrm{CH}_{4}$ followed similar emission patterns. Quantified gases were emitted from the mouth and nostrils of the animal.

To avoid alterations in normal feed-behavioral, sheep were previously acclimated to the devices used for measuring $\mathrm{CH}_{4}$. The devices were equipped with a nylon halter with three fixation points (mouth, lower jaw, and neck root behind the ears), a flow control valve, a particle filter, and a spiral hose with a quick connect in one end and a $445-\mathrm{cm}^{3}$ stainless cylinder (Figure 2). The other end of the hose, responsible for capturing the gases emitted to be stored in the cylinders, was fixed on the halter in a leather flap attached to the halter and placed over the muzzle near the animal's nostrils and mouth.

The cylinder was coupled to a bag attached to the back of the animal. The cylinder was cleaned previously with pure nitrogen 5.0 (degree of purity: 99.9\%, for application in chromatography with a Flame Ionization Detector-FID) and vacuum-emptied to contain negative pressure prior to each sample collection. The flow regulators were calibrated to allow a remaining vacuum in the cylinder of 
about $500 \mathrm{mb}$ (which represents half of the total cylinder volume) at the end of the sample collection period. The inlet regulator was calibrated for each collection period of 4 consecutive days. Two cylinders (blanks) were distributed in the area at a height similar to that of the grazing animals' reach for correction of the gases contained in the environment. The flow of $\mathrm{CH}_{4}$ emitted by the animal was calculated by correlating it with the $\mathrm{SF}_{6}$ flow, since the tracer gas release rate in the rumen had been determined previously [29].

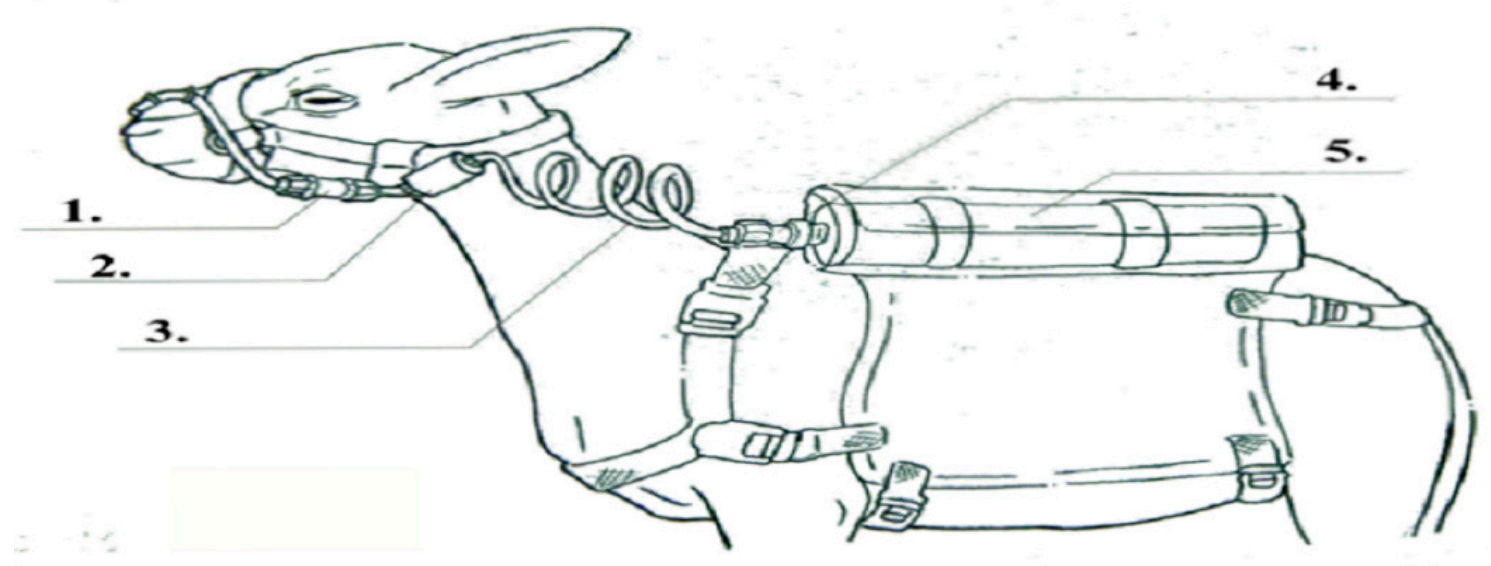

Figure 2. Components of the device used for measuring $\mathrm{CH}_{4}$ emission. Illustration of components to collect $\mathrm{CH}_{4}$ : 1. Flow control valve; 2 . particle filter; 3 . spiral hose; 4 . quick connect; 5 . stainless cylinder.

$\mathrm{CH}_{4}$ emission values were calculated in $\mathrm{g} /$ day. Based on these results, inter-relationships were made with productive parameters, and $\mathrm{CH}_{4}$ emission was determined as a function of OM and NDF intakes (g/day and $\mathrm{g} / \mathrm{kgLW}^{0.75}$ ), total $\mathrm{CH}_{4}$ emission as a function of body weight gain in the period (WGP), and per kilogram of cold carcass.

\subsection{Chemical Analyses}

Ruminal extrusa and fecal samples were dried at $55^{\circ} \mathrm{C}$ for $72 \mathrm{~h}$, and, together with the concentrate, milled in a knife mill with $1 \mathrm{~mm}$ sieves. They were analyzed for DM (method 934.01), ash (method: 938.08), CP (method 968.06) in Nitrogen analyzer (Leco ${ }^{\circledR}$ CN628, St Josesh, MI, USA), and ether extract (EE) (method 920.39) according to the Association of Official Analytical Chemists International (AOAC 1990) [30]. OM was calculated as the difference between DM and ash content, Ash-free values of Neutral Detergent Fiber (aNDFom-NDF) and ADF were analyzed according to Goering [31], with adaptation for autoclave analysis according to Senger [32]. Acid detergent lignin (ADL) content was analyzed (method 973.18D) according to AOAC (1990) [30], neutral detergent insoluble nitrogen according to Licitra [33], and KL was analyzed by acid hydrolysis [34]. Total tannins were analyzed using the Folin-Ciocalteu method [35]. Concentrations of $\mathrm{CH}_{4}(\mathrm{ppm})$ and $\mathrm{SF}_{6}(\mathrm{ppt})$ were obtained by gas chromatography using electron capture $\left(350^{\circ} \mathrm{C}\right)$ and flame ionization $\left(250^{\circ} \mathrm{C}\right)$ detectors, respectively [36].

\subsection{Statistical Analyses}

A completely randomized design, with five replications (animals) per treatment, was used for the evaluation of $\mathrm{CH}_{4}$ emission in $\mathrm{g} /$ day and as a function of OM and NDF intakes (g/day and $\mathrm{g} / \mathrm{kgLW}^{0.75}$ ). Statistical differences of treatment parameters and periods were determined by the model below:

$$
\mathrm{Y}_{\mathrm{ijkl}}=\mu+\mathrm{T}_{\mathrm{i}}+\mathrm{a}_{\mathrm{ij}}+\mathrm{P}_{\mathrm{k}}+\left(\mathrm{T}^{*} \mathrm{P}\right)_{\mathrm{ik}}+\mathrm{e}_{\mathrm{ijk}}
$$


where $\mu=$ overall mean; $T_{i}=$ fixed effect of treatments (two degrees of freedom-DF) $(i=C T, Z n, P G)$; $\mathrm{a}_{\mathrm{ij}}=$ random residual effect associated with animal; $\mathrm{P}_{\mathrm{k}}=$ fixed effect of period (three DF) $(\mathrm{k}=\mathrm{March}$, April, May, June); $\left(\mathrm{T}^{*} \mathrm{P}\right)_{\mathrm{ik}}=$ treatment $^{*}$ period interaction $(\mathrm{six} \mathrm{DF})$; and $\mathrm{e}_{\mathrm{ijkl}}=$ experimental error associated with the animal observation in each month.

The following statistical model was used to evaluate $\mathrm{CH}_{4}$ emissions as a function of production parameters:

$$
\mathrm{Y}_{\mathrm{ijk}}=\mu+\mathrm{T}_{\mathrm{i}}+\mathrm{a}_{\mathrm{ij}}+\mathrm{e}_{\mathrm{ijk}}
$$

where $\mu=$ overall mean; $T_{i}=$ fixed effect of treatments $(i=C T, Z n, P G) ; a_{i j}=$ random residual effect associated with animal; and $\mathrm{e}_{\mathrm{ijk}}=$ experimental error associated with the observation.

Means were compared by the Tukey-Kramer test, with a significance of 0.05. The Proc GLM procedure of the Statistical Analysis System 9.0 (SAS Inst. Inc., Cary, SC, USA) was used.

\section{Results}

A greater amount of $\mathrm{g} \mathrm{CH}_{4}$ /day was emitted from PG compared with CT and Zn $(p<0.05$; Table 3). However, no effects $(p>0.05)$ of treatments were observed in OM and NDF intakes or emission expressed in $\mathrm{mg} \mathrm{CH}_{4}$ relative to $\mathrm{OM}$ and $\mathrm{NDF}$ intakes (g/day and $\mathrm{g} / \mathrm{kg} \mathrm{LW}{ }^{0.75}$ ). Among periods, greater $\mathrm{OM}$ and NDF intakes were observed in March and greater $\mathrm{g} \mathrm{CH}_{4} /$ day emission was observed in May; the same pattern was observed for $\mathrm{CH}_{4}$ in $\mathrm{mg} / \mathrm{OM}$ intake $\left(\mathrm{g} / \mathrm{day}\right.$ and $\left.\mathrm{g} / \mathrm{kg} \mathrm{LW} \mathrm{LW}^{0.75} ; p<0.05\right)$. There was no effect of period in $\mathrm{CH}_{4}$ emission as a function of NDF intake $(p>0.05)$.

Table 3. Effect of zinc or propylene glycol supplementation on nutrient intake and $\mathrm{CH}_{4}$ emission in sheep on Caatinga-native pasture.

\begin{tabular}{|c|c|c|c|c|c|c|c|c|c|c|c|}
\hline \multirow{2}{*}{ Variable $^{£}$} & \multicolumn{3}{|c|}{ Treatment $\ddagger$} & \multicolumn{4}{|c|}{ Period $^{\beta}$} & \multirow{2}{*}{ SEM ${ }^{¥}$} & \multicolumn{3}{|c|}{ P-value ${ }^{\dagger}$} \\
\hline & CT & Zn & PG & Mar & Apr & May & Jun & & $\mathbf{T}$ & $\mathbf{P}$ & $\mathbf{T} \times \mathbf{P}$ \\
\hline \multicolumn{12}{|c|}{ Intake, g/day } \\
\hline $\mathrm{OM}$ & 527 & 542 & 551 & $607^{a}$ & $539^{b}$ & $509^{b}$ & $505^{b}$ & 9.39 & 0.56 & $<0.01$ & 0.57 \\
\hline $\mathrm{NDF}$ & 231 & 236 & 246 & $279^{a}$ & $233^{b}$ & $235^{b}$ & $204^{c}$ & 5.47 & 0.33 & $<0.01$ & 0.52 \\
\hline \multicolumn{12}{|c|}{$\mathrm{CH}_{4}$ emission } \\
\hline g/day & $15.8^{b}$ & $15.6^{b}$ & $19.2^{\mathrm{a}}$ & $16.5^{\mathrm{ab}}$ & $17.2^{\mathrm{ab}}$ & $18.8^{\mathrm{a}}$ & $15.0^{b}$ & 0.56 & 0.01 & 0.04 & 0.11 \\
\hline $\mathrm{mg} / \mathrm{OM}$ & 30.0 & 29.0 & 35.0 & $27.9^{\mathrm{b}}$ & $32.2^{b}$ & $37.3^{\mathrm{a}}$ & $29.7^{b}$ & 1.24 & 0.09 & 0.04 & 0.11 \\
\hline $\mathrm{g} / \mathrm{OMkgLW}{ }^{0.75}$ & 0.29 & 0.30 & 0.35 & $0.27^{\mathrm{b}}$ & $0.31^{b}$ & $0.37^{\mathrm{a}}$ & $0.31^{\mathrm{b}}$ & 0.01 & 0.09 & 0.04 & 0.12 \\
\hline $\mathrm{mg} / \mathrm{NDF}$ & 69.9 & 68.9 & 79.4 & 61.1 & 75.6 & 81.0 & 73.3 & 2.89 & 0.17 & 0.07 & 0.18 \\
\hline $\mathrm{g} / \mathrm{NDFkgLW}{ }^{0.75}$ & 0.68 & 0.71 & 0.79 & 0.60 & 0.73 & 0.80 & 0.77 & 0.03 & 0.25 & 0.06 & 0.17 \\
\hline
\end{tabular}

${ }^{\mathrm{a}, \mathrm{b}}$ Means in the same row followed by different letters are different by the Tukey-Kramer test $(p<0.05) .{ }^{\ddagger} \mathrm{CT}=$ control; $\mathrm{Zn}=\mathrm{ZnSO}_{4} .7 \mathrm{H}_{2} \mathrm{O}$ addition for supply of $300 \mathrm{mg} \mathrm{Zn} /$ day in the salt; $\mathrm{PG}=$ addition of $2.5 \mathrm{~mL} / \mathrm{g} / \mathrm{kgLW}^{0.75} /$ animal$/$ day of propylene glycol mixed with the concentrate. ${ }^{\beta}$ Mar $=$ March Apr $=$ April; May $=$ May; Jun $=$ June. ${ }^{£} \mathrm{OM}=$ organic matter; $\mathrm{NDF}=$ neutral detergent fiber. ${ }^{¥} \mathrm{SEM}=$ standard error of the mean; ${ }^{\dagger} \mathrm{T}=$ treatments; $\mathrm{P}=$ period; $\mathrm{T} \times \mathrm{P}=$ interaction between treatments and periods.

There was no effect of treatments in production parameters $(p>0.05$; Table 4$)$. For total $\mathrm{CH}_{4}$ emission in the period from March to June, totaling 112 days of evaluation, greater values were observed in PG compared with CT and Zn $(p<0.05)$. There was no effect of treatments in $\mathrm{kg} \mathrm{CH}_{4} / \mathrm{kg}$ of body weight gain in the period, or $\mathrm{kg} \mathrm{CH}_{4} / \mathrm{kg} \mathrm{NDF}$ intake $(p>0.05)$. 
Table 4. Effect of zinc or propylene glycol supplementation on $\mathrm{CH}_{4}$ emission from sheep in sheep on Caatinga-native pasture and in relation with production parameters.

\begin{tabular}{|c|c|c|c|c|c|}
\hline \multirow{2}{*}{ Variable } & \multicolumn{3}{|c|}{ Treatment $\ddagger$} & \multirow{2}{*}{ SEM ${ }^{¥}$} & \multirow{2}{*}{$P$-value } \\
\hline & CT & $\mathrm{Zn}$ & PG & & \\
\hline & \multicolumn{5}{|c|}{ Production parameter } \\
\hline Cold carcass, in $\mathrm{kg}$ & 7.45 & 8.16 & 8.33 & 0.270 & 0.37 \\
\hline \multirow[t]{2}{*}{ Body weight gain in the period, in $\mathrm{kg}$} & 3.33 & 4.08 & 4.31 & 0.365 & 0.29 \\
\hline & \multicolumn{5}{|c|}{$\mathrm{CH}_{4}$ relation with production parameters } \\
\hline$\beta$ Total $\mathrm{CH}_{4}, \mathrm{~kg}$ & $1.81^{\mathrm{b}}$ & $1.71^{\mathrm{b}}$ & $2.20^{\mathrm{a}}$ & 0.057 & 0.01 \\
\hline $\mathrm{kg} \mathrm{CH}_{4} / \mathrm{kg}$ of total body weight gain & 0.688 & 0.411 & 0.700 & 0.072 & 0.09 \\
\hline $\mathrm{kg} \mathrm{CH} / / \mathrm{kg}$ of cold carcass weight & 0.248 & 0.209 & 0.271 & 0.009 & 0.12 \\
\hline
\end{tabular}

\section{Discussion}

To our knowledge, studies measuring the emission of $\mathrm{CH}_{4}$ in vivo in sheep in conditions of tropical semiarid regions, notably in the Caatinga biome, are scarce. It was important to understand how the great diversity of forages may contribute or not to emission of $\mathrm{CH}_{4}$, especially in the rainy season, a time of greater abundance of species. Allied to this, a few studies using Zn or PG as modulators in the rumen to mitigate the emission of $\mathrm{CH}_{4}$ in vivo in sheep have been reported. We tested the strategic use of these as additives in sheep grazing in areas of heterogeneous pasture aiming to improve the use of pastures and mitigate $\mathrm{CH}_{4}$ emission.

The lower OM and NDF intakes starting from April were affected by the quantity and quality of the pasture, which had lower in vitro DM and OM digestibility (Table 2). The maturation of the native Caatinga pasture during the rainy season greatly modifies the chemical-physical structure of the feeding environment [37]. According to these authors, there is a decrease in the herbaceous layer, and, at the same time, annual shrubby species grow during the months of January to May; from then on, these species become highly lignified, affecting diet quality.

Holter and Young [38] reported the relationship between $\mathrm{CH}_{4}$ emission and several dietary factors such as the diet chemical composition, nutrient intake, and digestibility. The decreased pasture quality (April to June) and lower intake may have contributed to the lower $\mathrm{CH}_{4}$ emission, especially in June (Table 3). On the other hand, greater intakes promote a reduction in $\mathrm{CH}_{4}$ emission per unit of feed ingested, which is directly related to alterations in the fermentation pathways and/or reduction of retention time [39]. In June, this last aspect seemingly contributed to the lower $\mathrm{CH}_{4}$ emission. The data from this study fall within normal ranges. Such an aspect reinforces the notion that differences in $\mathrm{CH}_{4}$ yield were related to variations in intake during the months. Another aspect that contributes to lower $\mathrm{CH}_{4}$ emission indirectly as a mitigator is the secondary's compounds [40]. Greater content of total tannins was verified in the pasture component obtained in June. This condition is also closely linked to lower $\mathrm{CH}_{4}$ emissions in the period. Changes in intake between low-quality and high-quality forages also resulted in changes in $\mathrm{CH}_{4}$ per $\mathrm{kg}$ OM intake [41]. According to the authors, the intake level and ruminal outflow, which are often positively correlated, partly explain this variability.

Minerals play an important role in the ruminal environment, e.g., by changing the osmotic pressure, buffer capacity, and dilution rate in the rumen. Kurihara et al. (1997) demonstrated that supplementation with $\mathrm{ZnSO}_{4}$ in ruminants' diets at levels greater than $1000 \mathrm{ppm}$ promoted reductions in ruminal protozoa population, which may result in decreasing $\mathrm{CH}_{4}$ emission. Moreover, later studies showed that greater levels of $\mathrm{Zn}$ in the diet increase propionate concentration and reduce the acetate:propionate ratio [14,23]. 
In this regard, we speculate that $\mathrm{Zn}$ addition could have increased propionate concentration in the rumen, which is considered an important hydrogen-competing pathway [12]. However, $\mathrm{CH}_{4}$ emissions originating from sheep in the $\mathrm{Zn}$ treatment were similar to that of animals receiving CT, with no effects of $\mathrm{Zn}$ on $\mathrm{CH}_{4}$ mitigation. Both of these treatments emitted lower $\mathrm{CH}_{4}$ levels than PG.

In a study investigating the effect of $\mathrm{ZnSO}_{4}$ supplementation in diets containing different levels of protein (6.5 and 8.5\% CP, and 8.5\% CP + $35 \mathrm{~g} \mathrm{ZnSO}_{4} /$ animal/day) for dairy cows, researchers observed that the possible ruminal protozoa reduction caused by zinc sulfate decreased $\mathrm{CH}_{4}$ in $\mathrm{L} / \mathrm{kg}$ $\mathrm{DM}$ by $60 \%$ [39]. In an experiment evaluating the effects of organic zinc supplementation $\left(\mathrm{ZnSO}_{4}\right.$ and Zn-peptides) in sheep, the authors observed that supplementation with Zn-peptides might result in a greater concentration of metabolizable energy and greater production of short-chain fatty acids [42]. Propylene glycol is metabolized in the rumen to lactate and propionate [43], allowing the capture of oxygen and reduction in $\mathrm{CH}_{4}$ production. However, $\mathrm{CH}_{4}$ emissions originated from animals on PG were 18.2\% greater, which was not expected. By contrast, the greater intake obtained in May contributed to greater emissions of $\mathrm{CH}_{4}$ as compared with June, probably due to the consumption of low-quality fractions, which implies longer retention of the fibrous fractions in the rumen.

Overall, tropical forages have greater proportions of fiber compared with temperate species, which contributes to acetic fermentation and greater production of $\mathrm{CH}_{4} \mathrm{~g} /$ day. On the other hand, this type of fiber has low digestibility, as observed in this study (Table 2), when slower fermentation rates were observed, implying lower amounts of substrate for methanogenic microorganisms [44].

The average emission flow in the present study was $16.9 \mathrm{~g} \mathrm{CH}_{4}$ animal/day, considering that animals had $24.0 \pm 1.81 \mathrm{~kg} \mathrm{LW}$, an average OM intake of $540 \mathrm{~g} / \mathrm{day}$, and $37.8 \%$ pasture IVOMD (Tables 2 and 3), yielding a supply of $204 \mathrm{~g}$ digestible $\mathrm{OM} /$ day. $\mathrm{CH}_{4}$ emissions as a function of $\mathrm{OM}$ and NDF intakes (31.3 and $72.7 \mathrm{mg} \mathrm{CH}_{4}$ /day, respectively) were not affected by the treatments, and the different months in the rainy season, except for the month of May, in which the greatest $\mathrm{CH}_{4}$ emission was recorded. Emission rates were greater than the $11.8 \mathrm{~g} \mathrm{CH}_{4}$ animal/day observed by Leuning et al [45]. Also, in their study, emissions were originated from sheep with $27.0 \mathrm{~kg} \mathrm{LW}$, a DM intake of $508 \mathrm{~g} /$ animal/day, and pasture DM digestibility of $69.5 \%$.

Evaluating the effect of supplementation with tropical tanniferous legumes as a strategy to mitigate $\mathrm{CH}_{4}$ emission in sheep with an average $\mathrm{LW}$ of $27.9 \pm 2.85 \mathrm{~kg}$, emissions were obtained in the range from 7.80 to $11.3 \mathrm{~g} \mathrm{CH}_{4} /$ day [46]. Another study determined enteric flow of $\mathrm{CH}_{4}$ of Somalis sheep with an average $\mathrm{LW}$ of $26.8 \pm 2.90 \mathrm{~kg}$, and 14.9 and $11.4 \mathrm{~g} \mathrm{CH}_{4}$ animal/day were observed for animals in enriched or unenriched thinned Caatinga areas, respectively [47]. Also, in that study, a flow of $13.0 \mathrm{mg}$ $\mathrm{CH}_{4} / \mathrm{g}$ OM consumed by animals in an enriched thinned Caatinga area during the rainy season was observed. Therefore, improvements in pasture use efficiency and of supplementation strategies may reduce $\mathrm{CH}_{4}$ emissions that originated from sheep.

Total $\mathrm{CH}_{4}$ emissions were $22.3 \%$ greater for PG treatment. These greater emissions were not expected, as previously discussed, because the inclusion of PG in the concentrate might have changed the fermentation pattern, resulting in lower $\mathrm{CH}_{4}$ emission. We believe that propylene glycol could have escaped ruminal fermentation and absorbed in the small intestine and converted to glucose in the liver [43]. Previous studies have indicated that propylene glycol can be rapidly absorbed from the rumen without affecting ruminal fermentation $[20,48]$. This aspect could have occurred, and although VFA was not evaluated, probably there were no changes in the acetate:propionate ratio, since acetate is directly related to $\mathrm{CH}_{4}$ production. Average $\mathrm{CH}_{4}$ emission per $\mathrm{kg}$ of cold carcass, or $\mathrm{kg}$ of product, was $0.243 \mathrm{~kg}$. The concept of $\mathrm{CH}_{4}$ emission intensity, based on emissions per unit of product, seems to reflect more precisely the effects of mitigation practices in intake, $\mathrm{CH}_{4}$ emission, and productivity of an animal [7].

The animals in this study had unsatisfactory performance, with lower body weight gain and carcass yields than expected. However, $\mathrm{CH}_{4}$ emissions based on productive parameters were not affected by the addition of $\mathrm{ZnSO}_{4}$ and propylene glycol. It is important to correlate $\mathrm{CH}_{4}$ emissions with productive parameters, as some studies indicate that ruminants raised on native pastures are the 
greatest $\mathrm{CH}_{4}$ emitters. For the development of inventories and establishment of mitigation practices, this information should be associated with the carbon footprint for production of meat and other animal products.

\section{Conclusions}

The results of this study indicate that Zinc sulfate and propylene glycol have no beneficial effects in mitigating $\mathrm{CH}_{4}$ emissions from sheep grazing native pastures in the Caatinga region. $\mathrm{CH}_{4}$ emissions from sheep grazing native pastures in the Caatinga region change throughout the rainy season due to fluctuations in availability and quality of pasture biomass. Moreover, the inclusion of zinc sulfate or propylene glycol did not improve animal feed intake, nutrient digestibility, and animal performance.

Author Contributions: Investigation: H.C. and E.S.; methodology: H.C., M.B., C.M., R.T., and A.L.B.; project administration: E.S. and H.C.; resources: E.S., A.P.F. and A.L.; writing—original draft: H.C.; writing—review and editing: A.P.F. and H.C., and Â.M.L.; statistical analysis: A.L. and Â.M.L. All authors have read and agreed to the published version of the manuscript.

Funding: This research was funded by the National Council for Scientific and Technological Development (Conselho Nacional de Desenvolvimento Cientifico e Tecnológico-CNPq, Process Number-CNPq 480786/2012-7) and for the Doctoral scholarship to H. Costa; as well as the Coordination for the Improvement of Higher Education Personnel (Coordenadoria de Aperfeiçoamento de Pessoal de Nivel Superior-CAPES) for granting the scholarship for the international internship. The supporting agencies participated neither in the study's design, data collection, and analysis, nor in the decision-making for preparation or publication of the manuscript.

Acknowledgments: The authors thank the Diego Galvani from Embrapa Goats and Sheep for his assistance with sample collection and support for laboratorial analyses.

Conflicts of Interest: The authors declare no conflicts of interest in the evaluation of the results from this experiment.

\section{References}

1. Van Dingenen, R.; Crippa, M.J.; Anssens-Maenhout, G.; Guizzardi, D.; Dentener, F. Global Trends of Methane Emissions and Their Impacts on Ozone Concentrations; Publications Office of the European Union: Brussels, Belgium, 2018; EUR29394EN; ISBN 9789279965500.

2. Tapio, I.; Snelling, T.J.; Strozzi, F.; Wallace, R.J. The ruminal microbiome associated with methane emissions from ruminant livestock. J. Anim. Sci. Biotechnol. 2017, 8, 7. [CrossRef] [PubMed]

3. Blaxter, K.L.; Clapperton, J.L. Prediction of the amount of methane produced by ruminants. Br. J. Nutr. 1965, 19, 511-522. [CrossRef]

4. Hook, S.E.; Wright, A.D.G.; McBride, B.W. Methanogens: Methane producers of the rumen and mitigation strategies. Archaea 2010, 2010, 50-60. [CrossRef] [PubMed]

5. Pedreira, M.d.S.; Primavesi, O. Aspectos ambientais na bovinocultura. In Nutrição de Ruminantes; Berchielli, T.T., Pires, A.V., Oliveira, S.G., Eds.; FUNEP: Jaboticabal, Brazil, 2011; pp. 521-535.

6. Grainger, C.; Williams, R.; Eckard, R.J.; Hannah, M.C. A high dose of monensin does not reduce methane emissions of dairy cows offered pasture supplemented with grain. J. Dairy Sci. 2010, 93, 5300-5308. [CrossRef] [PubMed]

7. Hristov, A.N.; Oh, J.; Firkins, J.L.; Dijkstra, J.; Kebreab, E.; Waghorn, G.; Makkar, H.P.S.; Adesogan, A.T.; Yang, W.; Lee, C.; et al. SPECIAL TOPICS - Mitigation of methane and nitrous oxide emissions from animal operations: I. A review of enteric methane mitigation options1. J. Anim. Sci. 2013, 91, 5045-5069. [CrossRef] [PubMed]

8. Pfister, J.A.; Malechek, J.C. The Voluntary Forage Intake and Nutrition of Goats and Sheep in the Semi-Arid Tropics of Northeastern Brazil. J. Anim. Sci. 1986, 63, 1078-1086. [CrossRef]

9. Andrade, E.M.; Meireles, A.C.M.; Palácio, H.A.Q. O semiárido cearense e suas águas. In O semiárido e o manejo dos recursos naturais; Andrade, E.M., Pereira Omar, P.J., Dantas, F.E.R., Eds.; Imprensa Universitária: Fortaleza, Brazil, 2010; pp. 71-94.

10. Beauchemin, K. Dietary mitigation of enteric methane from cattle. CAB Rev. Perspect. Agric. Vet. Sci. Nutr. Nat. Resour. 2009, 4. [CrossRef] 
11. O'hara, P.; Freney, J.; Ulyatt, M. Abatement of Agricultural Non-Carbon Dioxide Greenhouse Gas Emissions A Study of Research Requirements Report prepared for the Ministry of Agriculture and Forestry on behalf of the Convenor, Ministerial Group on Climate Change, the Minister of Agriculture; New Zealand Ministry of Agriculture and Forestry: Wellington, New Zealand, 2003; ISBN 0-478-07754-8.

12. Hungate, R.E. Quantities of Carbohydrate Fermentation Products. In The Rumen and its Microbes; Hungate, R.E., Ed.; Elsevier: New York, NY, USA, 1966; pp. 245-280.

13. Eryavuz, A.; Dehority, B.A. Effects of supplemental zinc concentration on cellulose digestion and cellulolytic and total bacterial numbers in vitro. Anim. Feed Sci. Technol. 2009, 151, 175-183. [CrossRef]

14. Arelovich, H.M.; Amela, M.I.; Martínez, M.F.; Bravo, R.D.; Torrea, M.B. Influence of different sources of zinc and protein supplementation on digestion and rumen fermentation parameters in sheep consuming low-quality hay. Small Rumin. Res. 2014, 121, 175-182. [CrossRef]

15. Garg, A.K.; Mudgal, V.; Dass, R.S. Effect of organic zinc supplementation on growth, nutrient utilization and mineral profile in lambs. Anim. Feed Sci. Technol. 2008, 144, 82-96. [CrossRef]

16. Kristensen, N.B.; Danfær, A.; Røjen, B.A.; Raun, B.-M.L.; Weisbjerg, M.R.; Hvelplund, T. Metabolism of propionate and 1,2-propanediol absorbed from the washed reticulorumen of lactating cows. J. Anim. Sci. 2002, 80, 2168. [CrossRef]

17. Kim, Y.K.; Choi, H.; Myung, K.H. Effects of propylene glycol on carcass traits and its related gene expression in Korean native steers. J. Anim. Sci. 2005, 83, 344-349. [CrossRef] [PubMed]

18. Czerkawski, J.W.; Breckenridge, G. Dissimilation of 1,2-propanediol by rumen micro-organisms. Br. J. Nutr. 1973, 29, 317-330. [CrossRef] [PubMed]

19. Nielsen, N.; Ingvartsen, K. Propylene glycol for dairy cows. Anim. Feed Sci. Technol. 2004, 115, $191-213$. [CrossRef]

20. Lane, S.F.; Hogue, D.E. Effects of butylene and propylene glycols on body composition and fatty acid synthetase in lambs. J. Anim. Sci. 1981, 53, 1473-1481. [CrossRef] [PubMed]

21. Araújo Filho, J.A. de Manejo Pastoril Sustentável da Caatinga | Instituto Interamericano de Cooperação para a Agricultura, 1st ed.; Projeto Dom Helder Camara: Recife, Brazil, 2013; ISBN 978-85-64154-04-9.

22. BDMEP. BDMEP-Banco de Dados Meteorológicos para Ensino e Pesquisa. Available online: http: //www.inmet.gov.br/portal/index.php?r=bdmep/bdmep (accessed on 16 August 2019).

23. Arelovich, H.M.; Owens, F.N.; Horn, G.W.; Vizcarra, J.A. Effects of supplemental zinc and manganese on ruminal fermentation, forage intake, and digestion by cattle fed prairie hay and urea. J. Anim. Sci. 2000, 78, 2972. [CrossRef] [PubMed]

24. NRC. Nutrient Requirements of Small Ruminants, 1st ed.; National Academies Press: Washington, DC, USA, 2007; ISBN 978-0-309-10213-1.

25. Faria, E.P.; Rodriguez, N.M.; Moreira, G.R.; Barbosa, I.; Sampaio, M.; Luiza, A.; Cruz, C.; Saliba, E.d.O.S.; Faria, E.P.; Rodriguez, N.M.; et al. Use of Infrared Spectroscopy to Estimate Fecal Output with Marker Lipe®. Int. J. Food Sci. Nutr. Diet. (IJFS) 2015, 1-10.

26. Olson, K.C. Diet Sample Collection by Esophageal Fistula and Rumen Evacuation Techniques. J. Range Manag. 1991, 44, 515. [CrossRef]

27. Tilley, J.M.A.; Terry, R.A. A two-satge technique for the in vitro digestion of forage crops. Grass Forage Sci. 1963, 18, 104-111. [CrossRef]

28. Saliba, E.O.S.; Pilo-Veloso, D.; Rodriguez, N.M.; Capanema, E.A.; Saliba, J.S.; Borges, A.L.C.C.; Gonçalves, L.C.; Borges, I.; Jayme, D.G.; Silva, R.R. Characterization of Lignin before and after Exposure to the Gastrointestinal Tract of Ruminants. Am. J. Anal. Chem. 2016, 7, 748-753. [CrossRef]

29. Johnson, K.A.; Johnson, D.E. Methane emissions from cattle. J. Anim. Sci. 1995, 73, 2483-2492. [CrossRef] [PubMed]

30. AOAC Official Methods of Analysis of AOAC International. Assoc. Off. Anal. Chem. Int. 1990, 15, CD-ROM.

31. Goering, H.K.; Van Soest, P.J. Forage Fiber Analyses; U.S. Department Government Printing Office: Washington, DC, USA, 1975; pp. 387-598.

32. Senger, C.C.D.; Kozloski, G.V.; Bonnecarrère Sanchez, L.M.; Mesquita, F.R.; Alves, T.P.; Castagnino, D.S. Evaluation of autoclave procedures for fibre analysis in forage and concentrate feedstuffs. Anim. Feed Sci. Technol. 2008, 146, 169-174. [CrossRef]

33. Licitra, G.; Hernandez, T.M.; Van Soest, P.J. Standardization of procedures for nitrogen fractionation of ruminant feeds. Anim. Feed Sci. Technol. 1996, 57, 347-358. [CrossRef] 
34. Hatfield, R.D.; Jung, H.-J.G.; Ralph, J.; Buxton, D.R.; Weimer, P.J. A comparison of the insoluble residues produced by the Klason lignin and acid detergent lignin procedures. J. Sci. Food Agric. 1994, 65, 51-58. [CrossRef]

35. Makkar, H.P. Effects and fate of tannins in ruminant animals, adaptation to tannins, and strategies to overcome detrimental effects of feeding tannin-rich feeds. Small Rumin. Res. 2003, 49, 241-256. [CrossRef]

36. Pinares-Patiño, C.S.; McEwan, J.C.; Dodds, K.G.; Cárdenas, E.A.; Hegarty, R.S.; Koolaard, J.P.; Clark, H. Repeatability of methane emissions from sheep. Anim. Feed Sci. Technol. 2011, 166, 210-218. [CrossRef]

37. Pfister, J.A.; Malechek, J.C.; Balph, D.F. Foraging Behaviour of Goats and Sheep in the Caatinga of Brazil. J. Appl. Ecol. 1988, 25, 379. [CrossRef]

38. Holter, J.B.; Young, A.J. Methane Prediction in Dry and Lactating Holstein Cows. J. Dairy Sci. 1992, 75, 2165-2175. [CrossRef]

39. Kurihara, M.; Shibata, M.; Nishida, T.; Purnomoad, A.; Terada, F. Methane Production and Its Dietary Manipulation in Ruminants. In Rumen microbes and digestive physiology in ruminants; Onodera, R., Itabashi, H., Ushida, K., Yano, H., Sasaki, Y., Eds.; Japan Scientific Societies: Tokyo, Japan, 1997; pp. 199-208. ISBN 4762208647.

40. Makkar, H.P.S.; Makkar, H.P.S. Treatment of Plant Material, Extraction of Tannins, and an Overview of Tannin Assays Presented in the Manual. Quantif. Tann. Tree Shrub Foliage 2013, 43-48.

41. Archimède, H.; Rira, M.; Eugène, M.; Fleury, J.; Lastel, M.L.; Periacarpin, F.; Silou-Etienne, T.; Morgavi, D.P.; Doreau, M. Intake, total-tract digestibility and methane emissions of Texel and Blackbelly sheep fed C4 and C3 grasses tested simultaneously in a temperate and a tropical area. J. Clean. Prod. 2018, 185, 455-463. [CrossRef]

42. Mallaki, M.; Norouzian, M.A.; Khadem, A.A. Effect of organic zinc supplementation on growth, nutrient utilization, and plasma zinc status in lambs. Turkish J. Vet. Anim. Sci. 2015, 39, 75-80. [CrossRef]

43. Cozzi, G.; Berzaghi, P.; Gottardo, F.; Gabai, G.; Andrighetto, I. Effects of feeding propylene glycol to mid-lactating dairy cows. Anim. Feed Sci. Technol. 1996, 64, 43-51. [CrossRef]

44. Van Soest, P.J. Nutritional ecology of the ruminant, 2nd ed.Comstock Pub; Cornel University: Ithaca, NY, USA, 1994; ISBN 0-8014-2772-X.

45. Leuning, R.; Baker, S.K.; Jamie, I.M.; Hsu, C.H.; Klein, L.; Denmead, O.T.; Griffith, D.W.T. Methane emission from free-ranging sheep: A comparison of two measurement methods. Atmos. Environ. 1999, 33, 1357-1365. [CrossRef]

46. Moreira, G.D.; Lima, P.d.M.T.; Borges, B.O.; Primavesi, O.; Longo, C.; McManus, C.; Abdalla, A.; Louvandini, H. Tropical tanniniferous legumes used as an option to mitigate sheep enteric methane emission. Trop. Anim. Health Prod. 2013, 45, 879-882. [CrossRef] [PubMed]

47. Mota, C.M. Fitossociologia e fluxo de emissão de metano entérico em áreas de Caatinga; Universidade Estadual Vale do Acaraú: Ceará, Brazil, 2014.

48. Clapperton, J.L.; Czerkawski, J.W. Metabolism of propane-1:2-diol infused into the rumen of sheep. Br. J. Nutr. 1972, 27, 553-560. [CrossRef] [PubMed]

(C) 2020 by the authors. Licensee MDPI, Basel, Switzerland. This article is an open access article distributed under the terms and conditions of the Creative Commons Attribution (CC BY) license (http://creativecommons.org/licenses/by/4.0/). 